\title{
Transient Depredation of Early Spring Range; Spotted Cut- worms [Amathes c-nigrum (L.)] as a Possible Cause
}

\author{
JOHN L. LAUNCHBAUGH AND CLENTON E. OWENSBY
}

\section{Abstract}

Destructive feeding by insects delayed early spring development of native shortgrass range nearly 2 months. Although the perennial grasses and most forbs recovered, growth of several plant species was prevented completely for one growing season. Evidence indicated spotted cutworm [Amathes c-nigrum (L.)] larvae may have been responsible.

Spring greenup of west-central Kansas native range usually begins in April. Plant development is well advanced by May 1, so it is highly unusual to find small-to-large areas with little or no green plant tissue at that time and for the condition to persist 1 to 2 months after surrounding vegetation has made normal growth. Nevertheless a half section range unit' ${ }^{\prime}$ containing over 40 ha with practically no new plant growth was observed initially in mid May, 1975 , the first time the area was checked after cattle were removed the previous fall. Adjacent to the large area were scattered spots up to $4 \mathrm{~m}$ in diameter which contained no visible green plants. Those eventually gave way to uninterrupted, actively growing vegetation. The late-developing vegetation was predominately shortgrass on a clay upland range site similar to that described by Launchbaugh (1967).

\section{Description of Problem}

The dominating feature of the affected vegetation was carryover slate gray plant residue from the past growing season with occasional green clones of stunted western wheatgrass [Agropyron smithii Rydb.]. The stark appearance of the residual weathered vegetation was heightened by contrasting, uniformly green, 20- to $30-\mathrm{cm}$ tall Japanese brome [Bromus japonicus Thunb.] and western wheatgrass in the surrounding, normally developing vegetation. Furthermore, there were no gradual transitions from affected to normal vegetation; all boundaries were abrupt and sharply defined. The few western wheatgrass clones were the only obvious living plants in a matrix of dormant, carry-over buffalograss [Buchloe dactyloides (Nutt.) Engelm.] and blue grama [Bouteloua gracilis (H.B.K.) Lag. ex Steud.] from the previous year, but tiller numbers and heights were markedly reduced compared with similar western wheatgrass clones in unaffected vegetation. Scattered representatives of other plants hidden by old residue showed various degrees of damage ranging from none to complete. Ball cacti [Mamillaria vivipara (Nutt.) Haw. and Neobesseya missouriensis (Sweet) B. \& R.] and scarlet globemallow [Sphaeralcea coccinea (Pursh) Rydb.] apparently were undamaged. Otherwise, Japanese brome, little barley [Hordeum pusillum Nutt.], western ragweed [Ambrosia psilostachya DC.], and Louisiana sagewort [Artemisia ludoviciana Nutt.] were absent; slimflower scurfpea [Psoralea tenuiflora Pursh] and purple poppymallow [Callirhoe involucrata (T. \& G.) Gray] were stunted, apparently from growing point removal. Common pricklypear [Opuntia humifusa Raf.] also appeared damaged to the extent no newly developing pads were found on plants in affected sites compared with normally developing ones on plants in the unaffected area. Warm-season perennial grasses, buffalograss, blue grama, and red and purple threeawn [Aristida longiseta Steud. and $A$. purpurea Nutt.] had no visible new growth until about June 1, 1975. Here and there, sheared leaf

Authors are research range scientist, Fort Hays Branch, Kansas Agr. Exp. Sta. Hays 67601; and research range scientist, Department of Agronomy, Kansas State University, Manhattan 66506.

This report is Contribution No. 312-J, Ft. Hays Branch Exp. Sta., KAES, Hays, and Contribution No. 1265-J, Department of Agronomy, KSU, Manhattan.

Mansucript received December 28, 1980.

Eleven $\mathrm{km}(7 \mathrm{mi})$ north $\times 16 \mathrm{~km}(10 \mathrm{mi})$ west of.WaKeeney, Kansas. tips of those plants had extended only 2 to $3 \mathrm{~mm}$ above the soil during the last week of May; clearly all had been cut off near the plant crowns earlier in the spring.

Although nearly all new spring growth was eliminated or inhibited, the cause was not readily apparent. Similar conditions were not known to have occurred there or on surrounding ranges before; nor had anyone observed or heard of smaller affected places in the vicinity which would have indicated a gradual buildup of a causative agent. The isolation of plant damage to sharply defined areas plus the lack of more conclusive signs pointed to concentrated activity by forms confined to the sites for a continuous period of time, e.g., insect larvae. Destructive feeding had to have occurred from late winter to late April, 1975, for the process to have abated before mid May, 1975. Thus, the earliness of feeding, closeness of cropping, short duration of activity, and wide variety of plants involved required a transitory, nonspecific herbivore. Although the most destructive feeding activity occurred earlier in the year, intensive searches in late May and early June, 1975, ultimately netted spotted cutworm [Amathes c-nigrum (L.)] larvae restricted to affected places; one of several species that could greatly reduce living plant cover then quickly disappear.

Plant foliar cover of the affected areas was only about $1 \%$ of normal on May 15, 1975; but, it increa sed to an estimated $80 \%$ of normal by August 15, 1975. Perennial plant basal cover, however, was less than $5 \%$ of normal in affected areas all summer. The large reductions in basal cover were conducive to temporary increases of weedy summer annuals that usually occur in only trace amounts in native range. There were scattered plants of buffalobur nightshade [Solanum rostratum Dunal] and pigweeds [Amaranthus spp.] along with large amounts of common witchgrass [Panicum capillare L.], which dominated the summer aspect of the affected areas until becoming overtopped by slimflower scurfpea in July. Species composition and basal cover gradually returned to normal by the end of the 1977 growing season, more than 2 years after the damage was done.

\section{Discussion}

A number of surface-feeding army cutworms and related forms are known to occur throughout the central Great Plains. Generally they are native to those grasslands. It was only after la rge acreages were converted to cultivated crop production that any were recognized as being economically important, and then only on cultivated crops (Whelan 1935, Walkden 1950, Painter et al. 1954). No mention has been made of outbreaks restricted to native grassland. Spotted cutworms, because they are general feeders and will assume an army-like habit, could have come from an unusually large fall hatch concentrated in the affected vegetation, passed the winter as partly grown larvae, done the observed damage, then pupated and moved on as adult moths without leaving more noticeable evidence than their feeding effects. Larvae of that species reportedly cannot survive midsummer heat in Kansas (Walkden 1950). Although identification of the destructive agent is by necessity conjectural, there were no suggestions of other insect, rodent, or rabbit activities in the form of diggings, droppings, access holes, pupal skins, or observable high population densities of animals on the move to account for the uniformly close removal of living vegetation in the affected areas. The type of damage and late-season regrowth of most perennial grasses precluded white grubs [Cyclocephala spp. and Phyllophaga spp.] or other root feeders from being responsible for the damage. Also, there were no signs of sod webworms [Crambus spp.]. Except for livestock graz- 
ing there were no indications of additional plant-tissue removal within or around the affected areas from late May, 1975, to the 1981 growing season. That and the lack of a gradual population buildup over several seasons clearly indicates the sudden appearance of a localized, evanescent "grazer."

Sporadic destruction of vegetation by transient pests has been known throughout history. In this century, there have been numerous popularized citings of grasshopper plagues related primarily to prolonged, severe drought. In addition, there have been outbreaks of other insects attacking native ranges, apparently for more subtle reasons. Examples include damage by black grass bugs [Labops spp. and Irbisia spp.] in Utah (Hawes et al. 1973), localized destruction by range caterpillars [Hemileuca oliviae Cockerell] in New Mexico and Colorado (Watts and Everett 1976), heavy infestations of sod webworms over large areas in South Dakota (Kantack 1975), and sod webworm-cutworm combinations, also on South Dakota ranges ${ }^{2}$.

Unpredictable destruction of native vegetation, particularly by unknown agents, evokes anxiety that such events may become commonplace rather than pass on, perhaps never to be repeated in the same locality. An unprecedented outbreak increases concern over introduced exotics or modification in feeding habits of indigenous forms. Native range vegetation has undergone an incredibly long selection process in becoming adapted to the stresses of the environment, including interacting influences of large and small grazers, sucking insects, fungi, and disease organisms. One would not expect, therefore, that normally benign users of range plants would suddenly become destructive, unless their potential in that respect were realized by the elimination of population-control factors or genetic changes in the feeders. In any case, such events are rare, generally ignored unless vast a reas are involved or may be erroneously attributed to known pests.

\section{Literature Cited}

Haws, B. Austin, Don D. Dwyer, and Max G. Anderson. 1973. Problems with range grasses? Look for black grass bugs! Utah Sci. 34:3-9.

Kantack, B.H. 1975. Sod webworm situation. South Dakota State Univ. Rep. prepared for the 3rd annual S.D. Trade Ass. Shortcourse., Jan. 6. 3 p. (mimeo).

Launchbaugh, J.L. 1967. Vegetation relationships associated with intensity of summer grazing on a clay upland range site in the Kansas 20- to 24-inch precipitation zone. Kansas Agr. Exp. Sta. Tech. Bull. 154. 24 p.

Painter, Reginald H., Harry R. Bryson, and Donald A. Wilbur. 1954. Insects that attack wheat in Kansas. Kansas Agr. Exp. Sta. Bull. 367. 47 p.

Walkden, H.H. 1950. Cutworms, armyworms, and related species attacking cereal and forage crops in the Central Great Plains. U.S. Dep. Agr. Cir. $849.52 \mathrm{p}$.

Watts, J.G., and Terry D. Everett. 1976. Biology and behavior of the range caterpillar. New Mexico Agr. Exp. Sta. Bull. 646. 32 p.

Whelan, Don B. 1935. A key to the Nebraska cutworms and armyworms that attack corn. Nebraska Agr. Exp. Sta. Res. Bull. 81. 27 p. 